Academic Voices

A Multidisciplinary Journal

Volume 3, No. 1, 2013

ISSN 2091-1106

\title{
TRENDS OF TAXATION IN NEPAL: A THEORITICAL REVIEW
}

\author{
Yadab Raj Sharma \\ Department of Economics, TU, Thakur Ram Multiple Campus, Birganj, Nepal \\ E-mail: Yadavrajsharama@yahoo.com
}

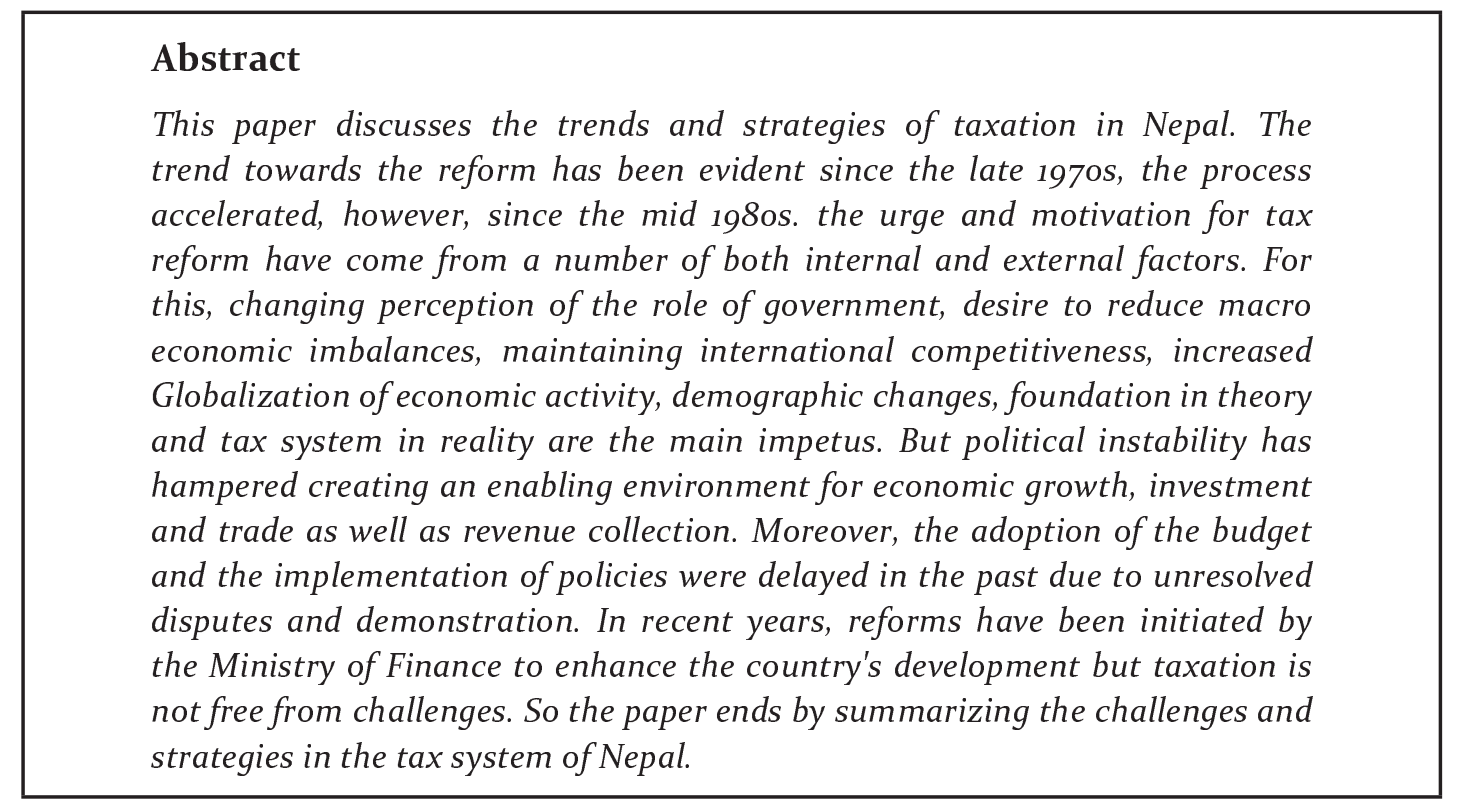

\section{Keywords}

Revenue; Trend; Tax-base; Tax compliance; Challenges; system; Economic growth

\section{Introduction}

It is open toa country toalteritslevel of taxation and the rate of growth through changes in the individual elements that constitute the tax structure. " Economic development depends, far more than is commonly recognized, on a carefully thought-out and well-organized tax structure" (Charles Mansfied, 1971). The position in late 1960 s was like this. As income increases, the share of income and pay roll taxes increased. In very poor countries, income taxes contributed between one sixth and one -fifth of total tax revenue, while they were the source of about one -half of the total tax revenue in the United State. Taxes on international trade were the main supplier of revenue in countries with per capita income 
up to $\$ 500$. Taxes on production and sales (excise and sales taxes) too occupied high position in these countries. Property tax never occupied only important position from the point of view of revenue through their share increased with per capita income. World Development Report 1988, says that there is a clear difference in the composition of taxes between industrial and developing countries and to a lesser extent between groups of developing countries. In advanced countries income and other direct tax account for 60 percent of total tax revenue. Of the direct tax, personal income tax contributes 27 percent of the total tax revenue and social security taxes make 31 percent. On average low and middle -income countries raise roughly 10 percent of their tax revenue through personal income taxes.

Following a long political conflict, Nepal is in a transaction period facing several challenges. The government has reiterated the need to generate more funds through internal sources to fulfill its core functions in providing public services and promote socio-economic development. Especially in view of future changes, internal revenue will be required to cover increasing demands of a growing population. But different aspects are influencing the tax policies in Nepal. The large informal economy, tax fraud and evasion insufficient information about the tax system, as well as limited organizational capacities have been identified to impede progress of the tax system. Over the years, tax policy in Nepal has evolved in response to the development strategy and its changes. From 1951, land revenue, custom duties and excise duties were in existence in Nepal. The Excise act, 1958 and the customs Act, 1962 consolidated respective laws and improved both the excise and customs system throughout the country. However, the foundation of the modern tax systems was initiated in 1959/60 after the introduction of income tax, urban house and land tax, and foreign investment tax, followed by sales in 1965 . In 1969/070, the foreign investment tax was merged with income tax. Furthermore, the corporate income tax was separated from the individual income tax in $1986 / 87$ when public corporation and public limited companies listed on the Nepal Stock Exchange were subjected to a flat corporate tax rate. This tax was extended to private limited companies in 1993/94. The Value Added Tax (VAT) was introduced in the Fiscal Year (FY) 1997/98, replacing the sales tax, Entertainment tax, Hotel Tax, and Contract Tax.

Trends of revenue collection in different Fiscal Year (From 1997/98 to 2010/11) shows that the share of VAT in total Tax revenue stand at 35.92 percent in FY 2010/11 with a propensity of further rise, together with the rise in consumption level, and has been established as the major source of revenue.

After accession to the WTO, the share of customs in the revenue collection has declined because the WTO membership made it obligatory for the Nepalese government to reduce tariff rates on imported goods and services. Excise duty has become more significant in raising government revenue currently comprising a number of around 22,80o registered taxpayers.

Except the above facts, this article covers the discussion of major challenges in the revenue mobilization, trend of various types of revenue collection in different Fiscal Years, trend of taxpayers' registration, PAN registrant, VAT registrant and tax evasion. Moreover challenges and strategies of taxation are also included in it.

\section{Metholodogy}

The study is entirely based on secondary sources of information -literature review has been conducted in order to collect information on various aspects, including trend and strategies of taxation in Nepal. The major literature comprises of studies after 1997, after which various reform steps 
have been taken in taxation field and the government of Nepal's tax reform agenda has been oriented towards increasing voluntary tax compliance, broadening the tax base by reducing compliance cost, promoting friendly services, encouraging investment and increasing the confidence of taxpayers. Reviewed studies have been presented and analyzed in different topics and subtopics. The study is conducted by agreeing upon the main theme and subthemes emerging from the information.

\section{Revenue}

The generation of domestic revenue and the efficient management of public finance play an essential role in functioning of government system. The fulfillment of tax obligations is necessary to investment in development programs to the benefit of all citizens. However different factors have an impact on the mobilization of revenue. "the major challenges in the revenue mobilization are major share of revenue based on import trade, small contribution of direct tax revenue, lack of information technology, unfriendly revenue administration, lack of desired amount of revenue collection even at broadening tax base, lack of effective control in revenue leakage, lack of adequate exercise to make tax policy stable and predictable, lack of adequate probe and actions taken to bring all under tax net or showing less participation not complying with tax liability, and also not providing effective encouragement to the people to participate in the tax net" (Three Year Plan -2010/11-2012/13).

In the past years, both the Nepalese tax system and the revenue authority have been modernized through various reform steps. The direction has been improving revenue productivity while minimizing cost. Especially efforts of the Inland Revenue Department (IRD) for efficient services and a transparent, fair application of tax laws have improved its perception by taxpayers.

\section{Tax and economic growth rates}

The estimate annual growth rate of almost two percent will cause the need to bring in more taxpayers under the tax net in order to mobilized distinctively more revenue and distribute the tax burden. Due to the large informal sector and a tendency to avoid taxes, revenues are currently dependent on a small share of registered taxpayer. The economic development is influenced by an inflation rate remaining of eight percent (june, 2012), the large informal sector estimated to be around 38.4 percent of the GDP and a high unemployment rate. The economic growth rate of Nepal is still one of the lowest among its neighboring countries with a modest four percent growth rate of the Gross Domestic Product (GDP) : Economic Growth Rates, World Economic Outlook 2011. (See table 1)

Due to unresolved political conflicts, industrial processes, trade and investment, tourism sectors have been disrupted in the past. Agriculture remains the major contributor to the GDP with a growth rate of 4.9 percent. Economic conditions have gradually changed and resulted in the restructuring of sectorwise contribution to GDP. The positive development of the macro -economic factor has led to an increase of revenue collection of about 22 percent (FY 2011/12) compared to previous Fiscal Year.

Table 1: Economic Growth Rate in different Fiscal Years

\begin{tabular}{|l|r|r|r|r|r|}
\hline \multirow{2}{*}{ Country } & \multirow{2}{*}{ 2008 } & \multirow{2}{*}{2009} & \multirow{2}{*}{2010} & \multicolumn{2}{c|}{ Forecast } \\
\cline { 5 - 6 } & & & & $\mathbf{2 0 1 1}$ & $\mathbf{2 0 1 2}$ \\
\hline Afghanistan & 3.6 & 20.9 & 8.2 & 8.0 & 7.5 \\
\hline Bangladesh & 6.0 & 5.8 & 6.0 & 6.3 & 6.6 \\
\hline Bhutan & 3.0 & 8.7 & 6.7 & 6.5 & 6.0 \\
\hline China & 9.6 & 9.2 & 10.3 & 9.6 & 9.5 \\
\hline India & 6.2 & 6.8 & 10.4 & 8.2 & 7.8 \\
\hline Maldives & 12.8 & 4.8 & 8.0 & 6.0 & 5.0 \\
\hline Nepal & 6.1 & 4.4 & 4.6 & 4.5 & 3.8 \\
\hline Pakistan & 1.6 & 3.4 & 4.8 & 2.8 & 4.0 \\
\hline Sri Lanka & 6.0 & 3.8 & 9.1 & 6.9 & 6.5 \\
\hline
\end{tabular}


Yadab Raj Sharma

Table 2: Trend of Various types of revenue collection in different Fiscal Years

(Rs. In billions)

\begin{tabular}{|l|l|l|l|l|l|l|l|l|}
\hline Fiscal Years & $\mathbf{1 9 9 7 / 9 8}$ & $\mathbf{2 0 0 2} / \mathbf{0 3}$ & $\mathbf{2 0 0 5 / 0 6}$ & $\mathbf{2 0 0 6 / 0 7}$ & $\mathbf{2 0 0 7 / 0 8}$ & $\mathbf{2 0 0 8 / 0 9}$ & $\mathbf{2 0 0 9 / 1 0}$ & $\mathbf{2 0 1 0 / 1 1}$ \\
\hline Custom duty & 8.5 & $\mathbf{1 2 . 7 8}$ & 15.34 & 16.71 & 21.06 & 26.79 & 35.15 & 35.66 \\
\hline VAT & 8.35 & 13.46 & 21.61 & 26.09 & 29.82 & 39.72 & 55.09 & 61.67 \\
\hline Income Tax & 4.9 & 9.84 & 10.94 & 15.73 & 19.08 & 27.25 & 33.82 & 41.71 \\
\hline Excise & 2.9 & 3.77 & 6.51 & 9.34 & 11.19 & 16.22 & 24.31 & 26.39 \\
\hline Land Duty and Registration & 1.29 & 1.04 & 3.03 & 3.25 & 4.01 & 7.07 & 7.93 & 6.22 \\
\hline Tax Revenue & 25.94 & 40.89 & 57.43 & 71.12 & 85.16 & 117.05 & 156.03 & 171.65 \\
\hline Non-tax Revenue & 7 & 13.64 & 14.85 & 16.59 & 22.47 & 26.42 & 23.65 & 29.18 \\
\hline Total Revenue & 32.94 & 54.53 & 72.28 & 87.71 & 107.63 & 143.47 & 179.95 & 200.83 \\
\hline Ratio of Custom Duty to GDP & 2.83 & 2.60 & 2.35 & 2.30 & 2.58 & 2.71 & 3.00 & 2.65 \\
\hline Ratio of VAT to GDP & 2.78 & 2.73 & 3.30 & 3.58 & 3.66 & 4.02 & 4.70 & 4.85 \\
\hline Ratio of IT to GDP & 1.63 & 2.00 & 1.67 & 2.16 & 2.34 & 2.76 & 2.89 & 3.10 \\
\hline Ratio of Excise to GDP & 0.96 & 0.77 & 1.00 & 1.28 & 1.37 & 1.64 & 2.07 & 1.96 \\
\hline Ratio of Tax Revenue to GDP & 8.62 & 8.31 & 8.78 & 9.77 & 10.44 & 11.85 & 13.34 & 12.74 \\
\hline Ratio of Non -tax to GDP & 2.33 & 2.77 & 2.27 & 2.28 & 2.75 & 2.67 & 2.02 & 2.17 \\
\hline Ratio of Total Revenue to GDP & 10.95 & 11.08 & 11.05 & 12.05 & 13.20 & 14.52 & 15.36 & 14.91 \\
\hline
\end{tabular}

Source: Economic Survey 2011, GoN

Trend of verious types of revenue collection

Nepal is acceded to the WTO, SAFTA and BIMSTEC. The WTO membership

madeitobligatory for the Nepalesegovernment to reduce tariff rates of imported goods and services. The share of customs tariff is on a declining trend and contribution of VAT has increase; a marginal rise in the share of direct taxes has been noticed. (see table 2)

Table 2 shows the trend of various types of revenue collection in different fiscal years. The shares of VAT, income tax and excise duties to GDP have increased to $4.58,3.10$ and 1.96 percent in FY 2010/11 from 2.78, 1.63 and 0.96 percent in FY 1997/98 respectively. Because of the slowly declining share of customs, Inland Revenue will foremost finance public expenditure.

Trend of share tax revenue from FY 2006/07 to FY 2011/12 has been shown in figure No. 1 (see figure 1)

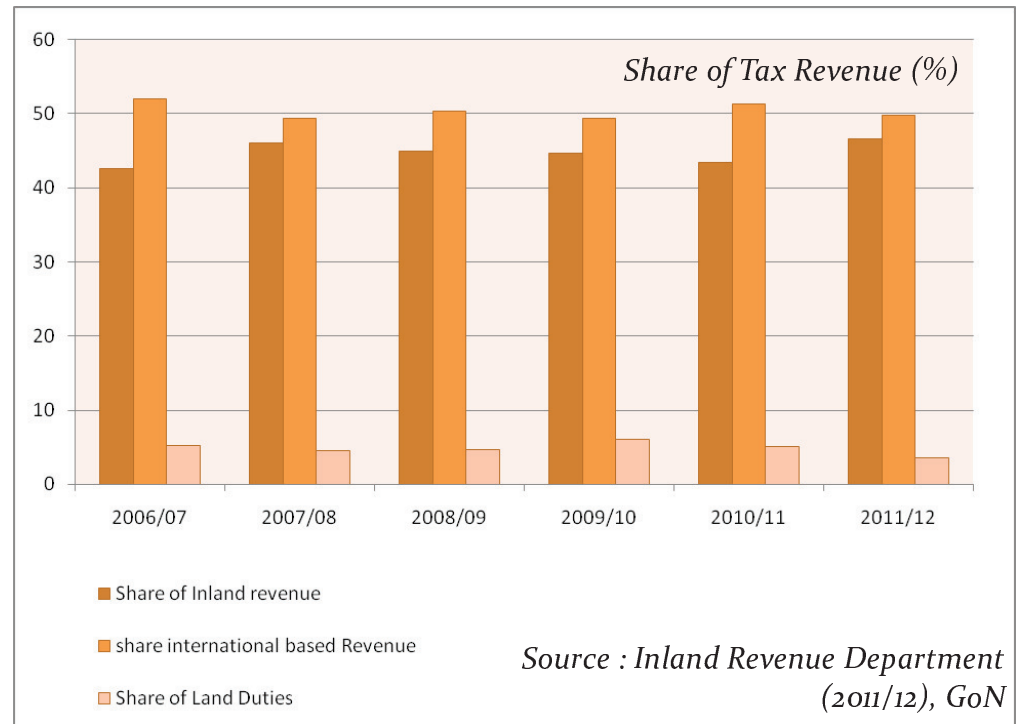

Figure 1: Trend of share of tax revenue from FY 2006/o7 to FY 2011/12 
Remittances have enhanced the consumption level and thus increased the VAT revenue substantially. The growing importance of global business, international trade and foreign employment changes the economic position of Nepal. Government expenditures are financed foremost by domestic revenue. The Share of tax revenue has increased to $85 \%$ of total revenue. Tax revenue to GDP ratio has increased from 8.62 percent in FY 1997/98 to 12.74 in FY 2010/11, whereas non-tax revenue hovered around less than 3 percent of the GDP. In 1997/98 the ratio of total revenue to GDP was 10.95, maintaining a steady growth, it reached 13.34 in 2009/10. However, it declined slightly to 14.9 percent in $2010 / 11$. The total public expenditure to GDP ratio stands at 22.16 percent (FY 2010/11), which caused a budget deficit of 6.8 percent of GDP.

\section{Tax base}

The tax base refers to expansion of taxable sectors. The taxpayers' registration has been positive over the year. In case of income tax, the trend shows that taxpayer's registration has been increasing at an average rate of 20.17 percent, where as in case of VAT, the average growth rate has been 21.09 percent over the last four years.

Figure 2 shows the trend of taxpayers' registration for the last five fiscal years. At the same time, the ratio of non-filers is also increasing.

\section{Tax compliance}

The primary goal of a revenue authority is to collect payable taxes and duties in accordance with the law. This needs to done in such a manner that it will sustain the confidence of the taxpayers in the tax system. The key determinants of tax compliance can be categorized as tax system structure (tax rate, penalty, detection, complexity of tax system), attitude and perception ( fairness, ethics), Non compliance opportunity(income level, income sources and occupation) and demographic factors(age, gender and education)

Table 3 reflects the total No. of PAN registrants, the percentage of non-filers, and the no. of returns in the last five fiscal years.

The compliance activity for VAT had not been significantly different from income tax. Around 21 percents taxpayers were nonfilers in FY 2010/11. A decreasing trend a debit returns has been observed in last five years, whereas the volume of credit and zero return have been gradually increasing.

\section{Tax evasion and tax fraud}

Tax evasion is an illegal attempt to reduce taxes to be paid to the government through non reporting, under reporting, making fraudulent changes in account books, maintaining multiple set of accounts, non

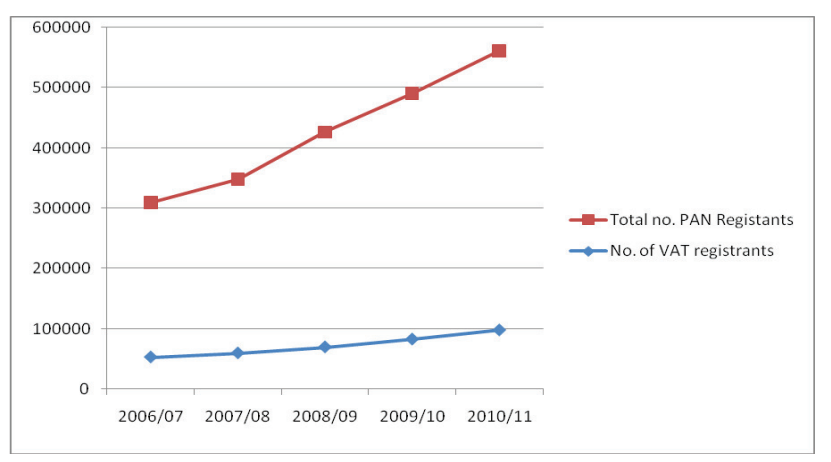

Source: IRD (2012/13), Ministry of Finance, GoN.

Figure 2: trend of taxpayers' registration in last five fiscal years. entering the transaction in account books, operating bank account under different names, doing business in dummy names, over reporting expenses, fragmenting income and transfer pricing (Indian tax Institute 1997:P.158). In Nepal, in 2012, 518 suspected VAT fraud were assessed worth Rs.6.6 billion, especially caused by the informal economy. Currently 495 new fraud cases and around 4,400 cases of mismatch data are under investigation. The number indicates a tendency of using fake 
Yadab Raj Sharma

Table 3: Total number of PAN registrants, percentage of Non-filers, and the no. of returns in the last five fiscal years.

\begin{tabular}{|l|l|l|l|l|l|}
\hline \multicolumn{1}{|c|}{ Fiscal Years } & \multicolumn{1}{c|}{$\mathbf{2 0 0 6 / 0 7}$} & $\mathbf{2 0 0 7 / 0 8}$ & $\mathbf{2 0 0 8 / 0 9}$ & \multicolumn{1}{|c|}{$\mathbf{2 0 0 9 / 1 0}$} & \multicolumn{1}{|c|}{$\mathbf{2 0 1 0 / 1 1}$} \\
\hline Total No. of PAN registrants & $\mathbf{2 5 6 , 4 2 1}$ & $\mathbf{2 8 8 , 6 7 0}$ & 356,855 & 407,471 & 463,378 \\
\hline Non -Filer (\%) & 82.65 & 58.74 & 55.51 & 57.93 & 58.36 \\
\hline Filer (\%) & 17.35 & 41.26 & 44.49 & 42.07 & 41.64 \\
\hline No. of Returns Collected & 44,500 & 119,119 & 158,771 & 171,404 & 192,943 \\
\hline
\end{tabular}

Source: IRD (2012-13), GoN

and false bills and invoices to evade tax, concerning vulnerable aspects of VAT noncompliance.

The level of VAT evasion and fraud influenced by the complexity of processes within the tax administration, government regulations, and systematic default in VAT design and implementation weakness. Fraud in treble services is rather difficult to detect. Improvement in the quality of audit and investigation, as well as application of available legal provisions, is needed to tackle fraud

\section{Challenges}

While reforming the tax system, it is critical to achieve fiscal consolidation, minimize distortion in the economy, and create a stable and predictable environment for the markets to function. The wave of internationalization of economic activities across the world in the 1990s necessitated the alignment of tax policy of Nepal's development strategy, which required a wide range of tax reforms. In order to bring the informal sector into the tax net and enhance voluntary tax compliance, compliance cost need to be reduced through different approaches and mechanisms. A complex, unpredictable tax system and inconsistent laws increase the probability for non compliance. It is needed to establish a taxpayer friendly environment by providing accessible information and services in order to create a better understanding on tax legislation and administrative processes. Tax systems with a low risk of detection motivate citizens to avoid the registration topay taxes. In order to effectively mitigate non- compliance and to take efficient action against tax fraud and evasion, enforcement mechanism should be strengthen. Limited resources, technical capacities and infrastructure impede quality services throughout the country. A competent Human Resources System is the prerequisite to initiate change process. Change process within an organization requires new ideas and team play to progress and succeed with reform efforts. The purpose of the integration IT-assisted systems is multifunctional. It simplifies administrative operation, empowers taxpayers and enhances independency. It reduces compliance costs and fosters transparency through standardized processes.

\section{Conclusion}

The identified challenges necessitate change processes in order to improve the described environment for enhanced voluntary tax compliance. Improving the environment demands reform efforts broaden the tax net, including income tax, VAT and excise with its growing relevance. In this regard the institutionalization of compliance approaches and measures will be crucial and influential also for other areas, such as collection and enforcement. Reforms require efficient management and administration, as well as technical capacities supporting tax legislation. Simplified processes and tax 
laws contribute to a better understanding but also to an enhanced enforcement. Tax policy reform analyzes existing tax policies in view of implementation and implementation deficiencies. Harmonization of tax laws and procedural frame work on par with international standards initiate the establishment of dispute settlement mechanism so that taxpayers are assured for having an institutionalized and permanent entity for efficient service delivery on matters of tax demands, long outstanding tax disputes and arrears. Taxpayer services and education should beimproved. Providing efficient service is not only an obligation but is a pre-condition to raise the level of voluntary compliance. There should be optimal uses of modern technology. It can change the perception and ambition of the taxpayers to be served quickly, fairly and efficiently which needs continuity, effectiveness and uninterrupted services.

\section{References}

Chander, Prakash and Louis, Wilde (1992), corruption in Tax Administration, Journal of public Economics, Vol. 49,333-349.

Dahal, Madan Kumar (1991), Tax Structure and Policy Framework in Developing Countries, The Economic Journal of Nepal, Vol. 14, No. 2, 1-17

Harvard University (1997) Tax Reform in Nepal: A Comprehensive Review, Massachusetts: Harvard University, USA

Inland Revenue Department, (2012/13), Strategic Plan, Kathmandu: Ministry of Finance, Government of Nepal.

Mittal, S.N., (1989) Taxation Policies and Financial Decisions. New Delhi: V.K. Publishing House.

Prapanna. A. (2062), Reference book on Taxation in Nepal, Kathmandu: Dhaulagiri Books and Stationeries. 